\title{
TINGKAT PENGETAHUAN IBU TENTANG PEMBERIAN MP-ASI DI DESA NGUNUT JUMANTONO KARANGANYAR
}

\author{
Ernawati \\ Pascasarjana Ilmu Kesehatan Masyarakat Universitas Sebelas Maret
}

\begin{abstract}
Keywords: Level Of Knowledge, Provision Of Complementary Feeding. Keberhasilan granting MP BREAST MILK is influenced by a variety of factors, one of which is the level of knowledge. Results of a survey in village Jumantono Ngunut septi Karanganyar by conducting interviews with midwives, village that the knowledge of the mother in each village in giving BREAST MILK to her baby to varied valid any know about giving MP ASI but there are some mothers who are less knowledgeable about granting MP ASI. The goal in this research is to know the level of knowledge about givingmom MP ASI in the village Jumantono KaranganyarJenis Ngunut this research is quantitative descriptive. The population of this research are all mothers who have babies in the village Jumantono Ngunut Karanganyar. Researchon sample is the mother who has toddlers aged 0-2 years in the village of Jumantono Ngunut Karanganyar totalling 72 respondents. This instrument is used in is the questionnaire. Data processing stages: cleansing, coding, skoring, insert, data analysis that is used in is a frequency distribution and percentage of a variable. The results of the research note that the characteristicsof the respondents based on level of education ELEMENTARY education level prevailing majority of 23 respondents (31.9\%) with enough knowledge level as many as 20 respondents (87,0\%). Characteristics of respondents based on majority parity is parity 1 applies 35 respondents (48.6\%) with enoughknowledge level as much as 28 respondents (80,0\%). Characteristics of respondents based on age of majority age of 21-35 years as many as 67 respondents $(93,1 \%)$ with enough knowledge level as much as 52 respondents (77,6\%). The characteristics of resonden based on the work of the majority is a Housewife (IRT) as much as 40 respondents (55,6\%) with enough knowledge level as much as 87.5 of respondents (35\%). Summary of the research isknowledge about giving mom MP ASI in the village Jumantono Ngunut Karanganyar largely had enough knowledge level of 57 respondents $(79,2 \%)$
\end{abstract}

Keywords: Level Of Knowledge, Provision Of Complementary Feeding

\begin{abstract}
Abstrak : Tingkat Pengetahuan, Pemberian Makanan Komplementer. Keberhasilan pemberian MP-ASI dipengaruhi oleh berbagai faktor salah satunya adalah tingkat pengetahuan. Hasil survey pendahuluan di Desa Ngunut Jumantono Karanganyar dengan melakukan wawancara dengan bidan desa bahwa pengetahuan ibu pada masing-masing dusun dalam memberikan ASI kepada bayinya bervariasi yaitu ada yang mengetahui tentang pemberian MP-ASI tetapi ada beberapa ibu yang kurang mengetahui tentang pemberian MP ASI. Tujuan dalam penelitian ini adalah untuk mengetahui tingkat pengetahuan ibu tentang pemberian MP-ASI di Desa Ngunut Jumantono Karanganyar
\end{abstract}


Jenis penelitian ini adalah deskriptif kuantitatif. Populasi penelitian ini adalah semua ibu yang mempunyai balita di Desa Ngunut Jumantono Karanganyar. Sampel pada penelitian adalah ibu yang mempunyai balita umur 0 bulan -2 tahun di Desa Ngunut Jumantono Karanganyar yang berjumlah 72 responden. Instrumen yang digunakan adalah kuesioner. Tahap pengolahan data : cleaning, coding, skoring, entering, Analisa data yang digunakan adalah distribusi frekuensi dan persentase dari variabel. Hasil penelitian diketahui bahwa karakteristik responden berdasarkan tingkat pendidikan mayoritas tingkat pendidikan SD yaitu 23 responden (31,9\%) dengan tingkat pengetahuan cukup sebanyak 20 responden (87,0\%). Karakteristik responden berdasarkan paritas mayoritas adalah paritas 1 yaitu 35 responden $(48,6 \%)$ dengan tingkat pengetahuan cukup sebanyak 28 responden $(80,0 \%)$. Karakteristik responden berdasarkan umur mayoritas berusia 21 - 35 tahun sebanyak 67 responden $(93,1 \%)$ dengan tingkat pengetahuan cukup sebanyak 52 responden (77,6\%). Karakteristik resonden berdasarkan pekerjaan mayoritas adalah Ibu Rumah Tangga (IRT) sebanyak 40 responden $(55,6 \%)$ dengan tingkat pengetahuan cukup sebanyak 35 responden (87,5\%). Simpulan dari penelitian ini adalah pengetahuan ibu tentang pemberian MPASI di Desa Ngunut Jumantono Karanganyar sebagian besar mempunyai tingkat pengetahuan cukup 57 responden $(79,2 \%)$.

Keywords: Tingkat Pengetahuan, Pemberian Makanan Komplementer.

\section{PENDAHULUAN}

Angka Kematian Bayi (AKB) menurut data Survey Demografi Kesehatan Indonesia (SDKI) tahun 2012 yaitu 34 per 1000 kelahiran hidup. Data Propinsi Sulawesi Utara untuk AKB pada tahun 2012 sebesar 37 per 1000 kelahiran hidup, dan tahun 2013 tercatat bayi yang meninggal sebanyak 49 bayi dan 9 bayi diantaranya meninggal disebabkan karena diare (Kusmiyati,dkk, 2014). Departemen Kesehatan mencatat masalah gizi sebagai salah satu penyebab kematian balita sebesar 0,5\% (Arisman, 2012).

Data di Indonesia menunjukkan status gizi bayi 0-6 bulan sebesar $6,5 \%$ termasuk gizi buruk; $8,2 \%$ termasuk dalam gizi kurang; $76,7 \%$ termasuk gizi baik dan $8,7 \%$ termasuk gizi lebih. Tahun 2010 di Indonesia bayi yang mendapat ASI dan makanan cair (predominan) sebesar 4,5\%; bayi yang mendapat ASI dan MP-ASI dini (parsial) sebesar
81,54\%; sedangkan untuk cakupan status gizi bayi 0-6 bulan pada tahun 2010 adalah 4,2\% termasuk gizi buruk; $7,2 \%$ termasuk dalam gizi kurang; $82,3 \%$ termasuk gizi baik dan $6,2 \%$ termasuk gizi lebih. Status gizi di Indonesia sebagian besar memang sudah baik, namun masih ada pula bayi yang memiliki gangguan status gizi seperti gizi buruk, kurang dan bahkan ada yang status gizi lebih (Wargiana, dkk, 2013).

Untuk mencapai tumbuh kembang optimal, di dalam Global Strategi For Infrant And Young Child Feeding, Wordl Health Organization (WHO) dan United International Childrens Emergency Fund (UNICEF) merekomendasikan empat hal penting yang harus dilakukan yaitu : Pertama, memberikan Air Susu Ibu kepada bayi segera dalam waktu 30 menit setelah bayi lahir. Kedua, memberikan hanya Air Susu Ibu (ASI) saja atau pemberian ASI secara eksklusif sejak lahir 
sampai bayi berusia enam bulan. Ketiga, memberikan makanan pendamping Air Susu Ibu (MP-ASI) sejak bayi berusia enam bulan sampai 24 bulan. Keempat, meneruskan pemberian ASI sampai anak berusia 24 bulan atau lebih (Depkes, 2006)

Lokasi penelitian ini adalah di Desa Ngunut Jumantono Karanganyar, alasan pemilihan lokasi ini karena berdasarkan survei pendahuluan jumlah populasinya lebih banyak, karakteristik penduduknya lebih heterogen dan jumlah sampel lebih banyak. Hasil wawancara dengan bidan desa diketahui bahwa pengetahuan ibu di dalam memberikan MP-ASI kepada bayinya bervariasi, ada yang mengetahui tentang pemberian MP-ASI tetapi ada beberapa ibu yang kurang mengetahui tentang pemberian MP ASI.

Faktor eksternal yang mempengaruhi pengetahuanterdiri dari faktor : 1) Ekonomi, dalam memenuhi kebutuahan primer ataupun sekunder, keluarga dengan status ekonomi baik lebih mudah tercukupi dibanding dengan keluarga dengan status ekonomi rendah, hal ini akan mempengaruhi kebutuhan akan informai termasuk kebutuhan sekunder. Jadi dapat disimpulkan bahwa ekonomi dapat mempengaruhi pengetahuan seseorang tentang berbagai hal. 2) Informasi, informasi adalah keseluruhan makna, dapat diartikan sebagai pemberitahuan seseorang adanya informasi baru mengenai suatu hal memberikan landasan kognitif baru bagi terbentuknya sikap terhadap hal tersebut. Pesan-pesan sugestif dibawa oleh informasi tersebut apabila arah sikap tertentu. Pendekatan ini biasanya digunakan untuk menggunakan kesadaran masyarakat terhadap suatu inovasi yang berpengaruh perubahan perilaku, biasanya digunakan melalui media masa. 3) Kebudayaan atau lingkungan, kebudayaan dimana kita hidup dan dibesarkan mempunyai pengaruh besar terhadap pengetahuan kita. Apabila dalam suatu wilayah mempunyai budaya untuk selalu menjaga kebersihan lingkungan maka sangat mungkin berpengaruh dalam pembentukan sikap pribadi atau sikap seseorang.

\section{METODE PENELITIAN}

Jenis penelitian yang digunakan adalah deskriptif yaitu metode penelitian yang dilakukan dengan tujuan utama untuk membuat gambaran atau deskriptif tentang suatu keadaan secara obyektif. Metode penelitian deskriptif digunakan untuk memecahkan atau menjawab permasalahan yang sedang dihadapi. Lokasi Penelitian di Posyandu di Desa Ngunut Jumantono Karanganyar dan dilaksanakan pada tanggal 10 - 20 Maret 2010. Populasi penelitian ini adalah semua ibu yang mempunyai balita di Desa Ngunut Jumantono Karanganyar. Sampel sebanyak 72 orang dengan teknik purposive sampling. Teknik pengumpulan data menggunakan kuesioner. Teknik analisis data menggunakan distribusi frekuensi dan presentase dari tiap variabel. Untuk mengetahui tingkat pengetahuan ibu maka digunakan perhitungan sebagai berikut :

Baik : Bila nilai responden yang diperoleh $(\mathrm{x})>$ mean $+1 \mathrm{SD}$

Cukup : Bila nilai responden mean -1 $\mathrm{SD} \leq \mathrm{x} \leq+1 \mathrm{SD}$

Kurang : Bila nilai responden yang diperoleh $(\mathrm{x})<$ mean-1 SD

\section{HASIL PENELITIAN}

1. Karakteristik Responden

a. Pendidikan 
Karakteristik responden berdasarkan pendidikan dapat dilihat pada tabel 1 .

\section{Tabel 1}

Distribusi Frekuensi berdasarkan Pendidikan Responden

\begin{tabular}{|c|c|c|c|}
\hline No & Pendidikan & Jumlah & Persentase $(\%)$ \\
\hline 1 & SD & 23 & 31,9 \\
\hline 2 & SMP & 22 & 30,6 \\
\hline 3 & SMA & 21 & 29,2 \\
\hline \multirow[t]{2}{*}{4} & PT/Sederajat & 6 & 8,3 \\
\hline & Total & 72 & 100 \\
\hline
\end{tabular}
bahwa umur responden sebagian besar berpendidikan SD 23 responden $(31,9 \%)$, SMP 22 responden $(30,6 \%)$, SMA 21 responden $(29,2 \%)$ dan Perguruan Tinggi atau sederajat 6 responden $(8,3 \%)$.

b. Paritas

Karakteristik

responden

berdasarkan paritas dapat dilihat pada tabel 2 .

Tabel 2

Distribusi Frekuensi berdasarkan Paritas

\begin{tabular}{cccc}
\hline No & Paritas & Jumlah & Persentase (\%) \\
\hline 1 & 1 & 35 & 48,6 \\
2 & 2 & 28 & 38,9 \\
3 & 3 & 5 & 6,9 \\
4 & 4 & 4 & 5,6 \\
\hline \multicolumn{5}{c}{ Total } & 72 & 100 \\
\hline \multicolumn{5}{c}{ Berdasarkan } & tabel & 2 & diketahui
\end{tabular}
bahwa responden sebagian besar responden dengan paritas 1 sebanyak 35 responden $(48,6 \%)$, paritas 2 sebanyak 28 responden $(38,9 \%)$, paritas 3 sebanyak 5 responden $(6,9 \%)$ dan paritas 4 sebanyak 4 responden $(5,6 \%)$.

c. Umur

Karakteristik

responden berdasarkan umur adalah sebagai berikut :
Tabel 3

Distribusi Frekuensi berdasarkan Umur Responden

\begin{tabular}{cccc}
\hline No & Umur & Jumlah & Persentase $(\%)$ \\
\hline 1 & $21-35$ & 67 & 93 \\
2 & $36-40$ & 4 & 5,5 \\
3 & $>40$ & 1 & 1,4 \\
\hline & Total & 72 & 100 \\
\hline
\end{tabular}

Berdasarkan tabel 3 diketahui bahwa umur responden sebagian besar berumur 21 - 35 tahun 67 responden (93\%), umur lebih dari 36 - 40 responden $(5,5 \%)$, umur $>40$ dan 1 responden $(1,4 \%)$.

d. Pekerjaan

Karakteristik responden berdasarkan pekerjaan dilihat pada tabel 4.

Tabel 4

Distribusi Frekuensi berdasarkan Pekerjaan Responden

\begin{tabular}{|c|c|c|c|}
\hline $\mathrm{No}$ & Pekerjaan & Jumlah & Persentase (\%) \\
\hline 1 & IRT & 40 & 55,6 \\
\hline 2 & Swasta & 22 & 30,6 \\
\hline 3 & Tani & 7 & 9,7 \\
\hline \multirow[t]{2}{*}{4} & PNS & 3 & 4,1 \\
\hline & Total & 72 & 100 \\
\hline
\end{tabular}
bahwa pekerjaan responden sebagian besar Ibu Rumah Tangga (IRT) 40 responden $(55,6 \%)$, Swasta 22 responden $(30,6 \%)$, Tani 7 responden $(9,7 \%)$ dan PNS 3 responden $(4,1 \%)$.

2. Analisis Univariat

a. Gambaran gambaran pengetahuan ibu tentang pemberian MP-ASI

Hasil gambaran pengetahuan ibu tentang pemberian MP-ASI dilihat pada tabel 5 . 
Tabel 5

Gambaran Pengetahuan Responden

\begin{tabular}{clcc}
\hline No & Pengetahuan & Jumlah & Persentase (\%) \\
\hline 1 & Cukup & 57 & 79,2 \\
2 & Kurang & 8 & 11,1 \\
3 & Baik & 7 & 9,7 \\
\hline & Total & 72 & 100 \\
\hline
\end{tabular}

Berdasarkan tabel 5 dapat dilihat pengetahuan ibu sebagian besar cukup 57 responden $(79,2 \%)$, pengetahuan Kurang 8 responden $(11,1 \%)$, dan pengetahuan Baik 7 responden $(9,7 \%)$

b. Pengetahuan berdasarkan pendidikan c.

Tabel 6

Cross Tabulasi Pengetahuan Berdasarkan Pendidikan

\begin{tabular}{|c|c|c|c|c|c|}
\hline \multirow[b]{2}{*}{ Pengetahuan } & \multicolumn{4}{|c|}{ Pendidikan } & \multirow[b]{2}{*}{ Total } \\
\hline & $\begin{array}{l}\text { SD } \\
(\%)\end{array}$ & $\begin{array}{l}\text { SMP } \\
(\%)\end{array}$ & $\begin{array}{c}\text { SMA } \\
(\%)\end{array}$ & $\begin{array}{c}\text { PT/Sederajat } \\
(\%)\end{array}$ & \\
\hline \multirow[t]{2}{*}{ Kurang } & 1 & 2 & 3 & 2 & 8 \\
\hline & 4.3 & 9.1 & 14,3 & 33,3 & \\
\hline \multirow[t]{2}{*}{ Cukup } & 20 & 16 & 17 & 4 & 57 \\
\hline & 87 & 72,7 & 81 & 66,7 & \\
\hline \multirow[t]{2}{*}{ Baik } & 2 & 4 & 1 & 0 & 7 \\
\hline & 8,4 & 18,2 & 4,8 & 0 & \\
\hline \multirow[t]{2}{*}{ Total } & 23 & 22 & 21 & 6 & 72 \\
\hline & 31,9 & 30,6 & 29,2 & 8,3 & 100 \\
\hline
\end{tabular}

Berdasarkan tabel 6 diketahui bahwa pengetahuan pendidikan SD untuk pengetahuan kurang 1 responden $(4,3 \%)$ Cukup 20 responden (87\%), Baik 2 responden $(8,4 \%), \quad$ pengetahuan pendidikan SMP pengetahuan kurang 2 responden $(8,4 \%)$, cukup 16 responden $(72,7 \%)$ pengetahuan Baik 4 responden $(18,2 \%)$, pendidikan SMA pengetahuan kurang 3 responden (14,3\%), pengetahuan cukup 17 responden $(81 \%)$, pengetahuan Baik 1 responden $(4,8 \%)$ dan untuk pengetahuan tingkat pendidikan PT/sederajat pengetahuan kurang 2 responden $(33,3 \%)$, pengetahuan cukup 4 responden $(66,7 \%)$ pengetahuan baik tidak ada.
d. Pengetahuan
responden berdasarkan pendidikan

Tabel 7

Cross Tabulasi Pengetahuan Berdasarkan Pendidikan

\begin{tabular}{lccccc}
\hline \multirow{3}{*}{ Pengetahuan } & \multicolumn{4}{c}{ Paritas } & \\
\cline { 2 - 5 } & 1 & 2 & 3 & 4 & Total \\
& $(\%)$ & $(\%)$ & $(\%)$ & $(\%)$ & \\
\hline Kurang & 5 & 2 & 1 & 0 & 8 \\
\multirow{4}{*}{ Cukup } & 6,9 & 2,8 & 1,4 & 0 & \\
\multirow{3}{*}{ Baik } & 28 & 25 & 2 & 2 & 57 \\
& 38,9 & 34,7 & 2,8 & 2,8 & \\
& 2 & 1 & 2 & 2 & 7 \\
& 2,8 & 1,4 & 2,8 & 2,8 & \\
\hline \multirow{2}{*}{ Total } & 35 & 28 & 5 & 4 & 72 \\
& 48,6 & 38,9 & 6,9 & 5,6 & 100 \\
\hline
\end{tabular}

Berdasarkan tabel 7 diketahui bahwa pengetahuan pada paritas 1 dengan pengetahuan kurang 5 responden $(6,9 \%)$ cukup 28 responden $(38,9 \%)$, baik 2 responden $(2,8 \%)$, paritas 2 dengan pengetahuan kurang sebanyak 2 responden $(2,8 \%)$, cukup 25 responden $(34,7 \%)$ pengetahuan baik 1 responden $(1,4 \%)$, paritas 3 dengan pengetahuan kurang 1 responden $(1,4 \%)$, pengetahuan cukup 2 responden $(2,8 \%)$, pengetahuan baik 2 responden $(2,8 \%)$ dan paritas 4 dengan pengetahuan kurang 0 responden $(0 \%)$, pengetahuan cukup 2 responden $(2,8 \%)$ pengetahuan baik sebanyak 2 responden $(2,8 \%)$.

e. Pengetahuan responden berdasarkan umur

Tabel 8

Cross Tabulasi Pengetahuan Responden Berdasarkan Umur

\begin{tabular}{|c|c|c|c|c|}
\hline \multirow[b]{2}{*}{ Pengetahuan } & \multicolumn{3}{|c|}{ Umur } & \multirow[b]{2}{*}{ Total } \\
\hline & $\begin{array}{c}21-35 \\
(\%)\end{array}$ & $\begin{array}{c}36-40 \\
(\%)\end{array}$ & $\begin{array}{l}>41 \\
(\%)\end{array}$ & \\
\hline \multirow[t]{2}{*}{ Kurang } & 8 & 0 & 0 & 8 \\
\hline & $11,9 \%$ & 0 & 0 & 11,1 \\
\hline \multirow[t]{2}{*}{ Cukup } & 52 & 4 & 1 & 57 \\
\hline & 77,6 & 100 & 1,8 & 79,2 \\
\hline \multirow[t]{2}{*}{ Baik } & 7 & 0 & 0 & 7 \\
\hline & 10,4 & 0 & 0 & 9,7 \\
\hline Total & 67 & 4 & 1 & 72 \\
\hline
\end{tabular}

Hasil tabel 8 menunjukkan bahwa pengetahuan responden untuk umur 21 35 tahun rata-rata pengetahuan cukup 52 
responden $(77,6)$, kurang 8 responden $(11,9 \%)$, baik 7 responden $(10,4 \%)$, umur 36 - 40 tahun rata-rata pengetahuan baik 4 responden $(100 \%)$, pengetahuan cukup dan kurang tidak ada. Sedangkan pada umur lebih dari 40 tahun, pengetahuan cukup 1 responden (100\%), untuk pengetauan kurang dan baik tidak ada.

$$
\text { f. Pengetahuan responden }
$$

Tabel 9

Cross Tabulasi Pengetahuan Responden Berdasarkan Pekerjaan

\begin{tabular}{lccccc}
\hline \multirow{3}{*}{ Pengetahuan } & \multicolumn{5}{c}{ Pekerjaan } \\
\cline { 2 - 5 } & $\begin{array}{c}\text { Tani } \\
(\%)\end{array}$ & $\begin{array}{c}\text { IRT } \\
(\%)\end{array}$ & $\begin{array}{c}\text { Swasta } \\
(\%)\end{array}$ & PNS & Total \\
\hline Kurang & 0 & 3 & 4 & 1 & 8 \\
& 0 & 7,5 & 18,2 & 33,3 & \\
Cukup & 5 & 35 & 15 & 2 & 57 \\
& 71,4 & 87,5 & 68,2 & 66,7 & \\
Baik & 2 & 2 & 3 & 0 & 7 \\
& 28,6 & 5 & 13,6 & 0 & \\
\hline Total & 7 & 40 & 22 & 3 & 72 \\
\hline
\end{tabular}

Hasil tabel 9 menunjukkan bahwa pengetahuan berdasarkan pekerjaan Tani pengetahuan cukup 5 responden $(71,4 \%)$, pengetahuan baik 2 responden $(28,6 \%)$, pengetahuan kurang tidak ada. Perkerjaan Ibu Rumah Tangga (IRT) pengetahuan rata-rata cukup 35 responden $(87,5 \%)$, pengetahuan kurang 4 responden $(18,2 \%)$, pengetahuan baik 3 responden $(13,6 \%)$. Swasta rata-rata pengetahuan cukup 15 responden $(68,2 \%)$, pengetahuan kurang 4 responden $(18,2 \%)$, pengetahuan baik 3 responden $(7,5 \%)$. Sedang untuk Pegawai Negeri Sipil (PNS) pengetahuan cukup 2 responden $(66,7 \%)$, pengetahuan kurang 1 responden $(33,3 \%)$, pengetahuan baik tidak ada.

\section{PEMBAHASAN}

Karakteristik responden dari tingkat pendidikan didapatkan sebagian besar adalah tingkat pendidikan SD yang terdiri dari 23 responden (31,9\%), pendidikan SD terdapat 20 responden dengan pengetahuan cukup, pengetahuan itu sendiri dipengaruhi oleh faktor pendidikan formal. Pengetahuan sangat erat hubungannya dengan pendidikan, dimana diharapkan bahwa dengan pendidikan yang tinggi maka orang tersebut akan semakin luas pula pengetahuannya. Akan tetapi perlu ditekankan, bukan berarti seseorang yang berpendidikan rendah mutlak berpengetahuan rendah pula. Hal ini mengingat bahwa peningkatan pengetahuan tidak mutlak diperoleh dari pendidikan formal saja, akan tetapi dapat diperoleh melalui pendidikan non formal. Pengetahuan seseorang tentang suatu obyek mengandung dua aspek yaitu aspek positif dan aspek negatif. Kedua aspek ini yang akan menentukan sikap seseorang, semakin banyak aspek positif dan obyek yang diketahui, maka akan menimbulkan sikap semakin positif terhadap obyek tertentu (Notoamodjo, 2010).

Sejalan dengan perkembangan perkembangan kebudayaan umat manusia cara manusia berfikir ikut berkembang. Dari sini manusia mampu menggunakan penalarannya dalam memperoleh pengetahuan. Pengalaman adalah guru terbaik demikian bunyi pepatah. Pepatah ini mengandung maksud bahwa pengalaman itu merupakan sumber pengetahuan. Hal ini dilakukan dengan cara mengulang kembali pengalaman yang diperoleh dalam memecahkan permasalahan yang di hadapi. Pada masa lain apabila cara yang digunakan tersebut orang dapat memecahkan masalah yang 
dihadapi, maka untuk memecahkan masalah lain yang sama, orang dapat pula menggunakan cara tersebut.

Hasil penelitian menunjukkan bahwa sebagian besar responden dengan paritas 1 sebanyak 35 responden $(48,6 \%)$, paritas 2 sebanyak 28 responden $(38,9 \%)$, paritas 3 sebanyak 5 responden $(6,9 \%)$ dan paritas 4 sebanyak 4 responden $(5,6 \%)$. Paritas dalam hal ini berarti pengalaman bagi ibu yang melahirkan di mana pengalaman merupakan salah satu faktor yang mempengaruhi pengetahuan seseorang. Hasil penelitian menyebutkan bahwa karakteristik responden sebagian besar berumur 21 - 35 tahun $(93,1 \%)$. Seorang individu dalam hidupnya selalu berinteraksi dengan lingkungan. Dengan berinteraksi tersebut, seseorang akan memperoleh skema. Skema berupa kategori pengetahuan yang membantu dalam menginterpretasi dan memahami dunia. Skema juga menggambarkan tindakan baik secara mental maupun fisik yang terlibat dalam memahami atau mengetahui sesuatu. Skema mencakup baik kategori pengetahuan maupun proses perolehan pengetahuan tersebut. Seiring dengan pengalamannya mengeksplorasi lingkungan, informasi yang baru didapatnya digunakan untuk memodifikasi, menambah, atau mengganti skema yang sebelumnya ada. (Piaget, 2008)

Tidak dapat mengajarkan kepandaian baru kepada orang yang sudah tua karena mengalami kemunduran baik fisik maupun mental. Dapat diperkirakan bahwa IQ akan menurun sejalan dengan bertambahnya usia, khususnya pada beberapa kemampuan yang lain seperti misalnya kosa kata dan pengetahuan umum. Beberapa teori berpendapat ternyata IQ seseorang akan menurun cukup cepat sejalan dengan bertambahnya usia.

Berdasarkan hasil penelitian, responden sebagian besar bekerja sebagai Ibu Rumah Tangga (IRT) 14 responden $(46,7 \%)$. Ibu yang bekerja adalah ibu yang melakukan aktifitas ekonomi mencari penghasilan baik di sektor formal maupun informal, yang dilakukan secara reguler di luar rumah. Tentunya aktifitas ibu yang bekerja akan berpengaruh terhadap waktu yang dimiliki ibu untuk memberikan pelayanan/kasih sayang terhadap anaknya termasuk perhatian ibu pada anak tersebut.

Pengetahuan mereka cukup tentang pemberian MP-ASI. Penginderaan terhadap obyek terjadi melalui panca indera manusia yakni penglihatan, pendengaran, penciuman, rasa dan raba dengan sendiri. Pada waktu penginderaan sampai menghasilkan pengetahuan tersebut sangat dipengaruhi oleh intensitas perhatian persepsi terhadap obyek. Sebagian besar pengetahuan manusia diperoleh melalui mata dan telinga. (Notoatmodjo, 2010)

\section{KESIMPULAN DAN SARAN}

1. Kesimpulan

Hasil penelitian menunjukkan bahwa pengetahuan ibu tentang pemberian MP-ASI di Desa Ngunut Jumantono karanganyar ASI sebagian besar dalam tingkat cukup 57 responden $(79,2 \%)$. Karakteristik responden dari tingkat pendidikan didapatkan sebagian besar adalah tingkat pendidikan SD yang terdiri dari 23 responden $(31,9 \%)$ dengan tingkat pengetahuan kategori cukup sebanyak 20 responden $(87,0 \%)$ Karakteristik responden berdasarkan paritas didapatkan sebagian besar adalah paritas 1 sebanyak 35 responden $(48,6 \%)$ dengan tingkat pengetahuan kategori cukup sebanyak 28 
responden (80,0\%). Hasil penelitian menyebutkan bahwa karakteristik responden sebagian besar berumur $21-35$ tahun sebanyak 67 responden $(93,1 \%)$ dengan tingkat pengetahuan kategori cukup sebanyak 52 responden $(77,6 \%)$. Berdasarkan hasil penelitian, responden sebagian besar bekerja sebagai Ibu Rumah Tangga (IRT) 40 responden $(55,6 \%)$ dengan tingkat pengetahuan kategori cukup sebanyak 35 responden $(87,5 \%)$.

2. Saran

a. Bagi Masyarakat

Diharapkan para ibu lebih memperluas pengetahuan mereka tentang pengetahuan menu MP-ASI kepada balita, dengan cara bertanya langsung kepada petugas medis ataupun mencari informasi melalui Posyandu, media cetak, media elektronika, baik TV maupun radio.

b. Bagi Institusi (Puskesmas)

Bagi Puskesmas hendaknya perlu mengadakan penyuluhan secara berkala dan intensif untuk meningkatkan pengetahuan ibu tentang MP-ASI dan terus memotivasi ibu-ibu untuk berperan aktif mengikuti kegiatan Posyandu.

c. Bagi Peneliti Selanjutnya Mengingat keterbatasan penelitian ini hendaknya dapat dilakukan penelitian lebih lanjut dengan mengembangkan variabel penelitian.

\section{DAFTAR RUJUKAN}

Arisman. (2012). Gizi dalam daur kehidupan, buku ajar ilmu gizi. Jakarta : EGC.

Kusmiyati, dkk. (2014). Hubungan Pengetahuan, Pendidikan Dan Pekerjaan Ibu dengan Pemberian Makanan Pendamping ASI (MP - ASI) pada Bayi di Puskesmas Bahu Kecamatan Malalayang Kota Manado. Jurnal Ilmiah Bidan. Vol 2 No 2.

Depkes RI. (2006). Pedoman Umum Pemberian Makanan Pendamping Air Susu Ibu (MP-ASI) Lokal. Depkes RI : Bakti Husada.

Notoatmodjo, S. (2010). Metodologi Penelitian Kesehatan. Jakarta: Rineka Cipta.

Piaget, J. (2007). Antara Tindakan dan Pikiran. Jakarta : Gramedia Pustaka Utama.

Wargiana, R, dkk. (2013). Hubungan Pemberian MP-ASI Dini dengan Status Gizi Bayi Umur 0-6 Bulan di Wilayah Kerja Puskesmas Rowotengah Kabupaten Jember. Jurnal Pustaka Kesehatan. Vol. 1 No.1. 